\title{
Integrating Web-Based English Instructional Materials to Promote Independent Learning
}

\author{
Aminah \\ Universitas Tadulako \\ Palu, Indonesia \\ amisuriaman@gmail.com
}

\author{
Mafulah \\ Universitas Tadulako \\ Palu, Indonesia
}

\begin{abstract}
The integration of technology in education settings has gained popularity particularly in the language teaching. The use of technology in the process of English Language Teaching (ELT) has brought certain benefits. It can increase motivation, decrease anxiety, provide students with authentic materials and audiences and the most important thing as the ultimate aim of this study is to promote students independent learning. Moreover, the using of web-based in the language pedagogy content is an important issue for ELT. Web-based English instructional materials aim to create students able to use webbased materials effectively for language learning. As web-based instruction provides the ubiquitous learning that students can learn anytime and anywhere through web-based materials, therefore, teachers should be able to develop and to integrate their instructional materials to fulfill the students need. Based on these reasons, this research explored the integration of web-based instructional materials in the teaching of English as a foreign language to enhance students' independent learning. To comprehend these objectives, the researcher employs an $R$ and $D$ (Research and Development) design by mixing quantitative and qualitative methods. The subjects of the study were the students of informatics study program of Tadulako university. The data were collected through semi-structured interviewed, study the related documents, and the results of questionnaire distribution. The data in these phases were analyzed quantitatively and qualitatively. Based on the analysis, the research found that the students demand of English learning materials are interactive and integrated with advance technology, such as, audio, video, and materials that access through internet. Learning English through web-based instruction has created positive impact for both lecturers and students and lead students to be independent learners. By the various supported activities and along with the flexible learning atmosphere and methods of delivery, the webbased English instructional materials are effective to promote students' independent learning.
\end{abstract}

Keywords- Instructional Material, Web-Based Instruction, Independent Learning

\section{INTRODUCTION}

As part of today's globalized society, Indonesia has placed particular focus on the teaching and learning of English. In Indonesia, English has become a compulsory subject taught in all schools from the primary to the tertiary level. Additionally, at the secondary level, English has been nominated as a core subject in the national examination, which is a prerequisite for passing the final test. Although English has been taught for years at school, it has not produced the expected results. Data from the Bureau of Statistics showed the proficiency of students in English is still below expectations. The teachercentered instructional approach in which the teacher does most of the talking and activities leaves little time for students to practice their English. This is the consequence of a teaching and learning process that still takes teacher-centered approach. As a result, students become dependent on the teacher to guide them in learning the language. This dependence can be partly explained as being related to the impact of the cultural perception of teaching and learning in many Asian countries, including Indonesia. Understandably, typical classrooms which are passive and compliant make the learning environment less motivating for students. Asian students take a low profile, rarely asking questions or volunteering answers, let alone making public observations or criticism of course content. Students place the teacher as the source of knowledge and, therefore, believe that he or she should not be challenged. The phenomenon has contributed to the dependency of most Indonesian students on the teacher and led them to teacher center due to the domination of the classroom by teachers. As a consequent, students have a limited time to learn and practice English both in groups and individually. This has made the process of English language teaching in Indonesia harder for students [1].

Despite the universal recognition of the importance of English at the tertiary level, the issues stated above have to some extent de-motivated students to learn the language. To make the students interested in learning the language, a more relaxed and unbound learning environment is essential. One way of creating such an environment is by encouraging the students to apply the concept of independent learning in which students are required to be more independent in selecting their learning materials and methods to fit their preferences [2].

The term independent learning leads to a single concept which is the move towards learner-centered approaches which view learners as individuals with unique needs and rights [3]. Independent learning is implemented under the control and guidance of the teachers. All teaching activities can facilitate the learners' initiative and participation, and are aimed at cultivating the learners' language skills. The outside class activities, which are completely autonomous learning, are an indispensable part of language knowledge construction. They guarantee the learners' consolidation and expansion of the 
knowledge acquired in the classroom activities. Therefore, classroom and outside activities make up an integral part of the whole learning process. Teachers assign learning tasks to students and offer them direction and guidance while learners are encouraged to carry out their learning and to achieve English language output [4].

In order to develop methods to encourage independent learning, it is necessary to choose appropriate teaching technique and media that can cover all the problems faced by the students. In my point of view, by integrating technology such as the internet as a medium in the process of teaching and learning, it is potential to add the value to the learning process and to increase students' attention and motivation.

The introduction of computer technology and specifically the internet has had significant effects on second/foreign language teaching and learning [5]. Computer technology serves as an excellent tool for language acquisition, and research has shown that students are highly motivated when using computers and hence learning better when they are relaxed and motivated [6]. In other words, the instructional process by integrating technology is likely to make teaching more successful and more attractive. Technology is used in almost every aspect of instruction and learning and it has been known to promote and facilitate learning.

The World Wide Web has emerged rapidly to become the premier electronic medium. Many institutions have adopted the World Wide Web as one of the feasible delivery methods for learning activities. The Web provides opportunities to develop new learning experiences for students which is not possible conducted in conventional teaching method. Furthermore, the web is a medium of learning and instruction that has a potential to support the creation of well-designed resources [7]. Webbased instructional materials can provide teachers and students with a broad range of new and exciting experiences that sometimes are impossible to duplicate in a traditional classroom. Developments in Web based learning have provided students with a wide variety of teaching/learning alternatives that have expanded the educational process beyond the traditional classroom. Several studies have shown that students who used Web-based instructional materials and practice find learning more enjoyable. They appreciate the freedom provided on computers to do experiments, spend long hours at a computer to complete a task, and enjoy testing out new [8]. Web-based instructional materials include potentially powerful tools for enhancing teaching and learning processes in education.

These learning materials attract students' attention and facilitate their acquisition of the related language knowledge. Web-based instructional materials as supplementary resources for teaching English can promote classroom interaction to maximize opportunities for students to put English to a genuine use and to create a student-centered learning environment.

In response to student independent learning, Web-based instructional materials were introduced to accommodate this approach. The Web-based instructional materials are supplementary resources for teaching that aims learners to acquire the right knowledge skills in order to function as active, self-reflected, and collaborative learners [9]. Furthermore,
Hadjerrouit stated that Web-based Language Learning Resource has the potential to support a learning environment in which students explore knowledge and enhance their learning. He added that a learning environment in this context is one in which the students can control their learning, under the guidance of the teacher, and the order in which they learn and perform activities based on their needs. It indicates the ultimate aim of introducing Web-based instructional materials is in line with independent learning approach where the student takes their own responsible for their learning. By integrating interactive, attractive, challenging learning materials such as Web-based instructional materials will make learning environment lively. It is expected the Web-based English instructional materials that developed by teachers facilitates the students to improve their interest and motivation in learning English. This is also supported by the study result conducted concerning the positive perception both teachers and students toward the integration of technology such as web-based instructional materials on the process of teaching and learning [10].

\section{METHOD}

This study is categorized as research and development ( R \& D) which focus on the development of the English instructional materials based-web for students of informatics faculty of Engineering Tadulako university. To obtain the objective, the researchers voluntarily invited 5General English Course (MKU) lectures and 125 students from three classes as the subjects of this study.

Three techniques: questionnaire distributions, interviews, and documentation were administered to gather data which articulate the needs assessment. To do so, the instruments: questionnaire, interview guideline, and list of document evaluation were used to take data. Questionnaire was designed to reveal the learning needs and target needs as the basis of the development of the web-based English instructional material. This questionnaire was distributed to students of Informatics. The interview guideline was designed to get data from the English lecturer of MKU. In the interview, the English teachers were questioned under the issue of the web-based English instructional materials and the issue of its development. The gathered data were then analyzed with the use of descriptive qualitative method.

\section{RESULT AND DISCUSSION}

In reference to the need analysis, the following presents some findings. First, it is evident that all respondent students agree to the issue of developing the web-based English instructional materials as this triggers student to encourage and motivate to study English which lead them to study independently. As can be seen from the following data both responds of students and lecturers concerning their response towards the web-based English instructional materials.

\begin{tabular}{|l|l|l|l|l|}
\hline No & Statements & Score & Percentage & Classification \\
\cline { 2 - 4 }
\end{tabular}




\begin{tabular}{|c|c|c|c|c|}
\hline 1 & $\begin{array}{l}\text { Learning English via } \\
\text { Web- based } \\
\text { Instructional model is } \\
\text { a modern way of } \\
\text { learning. }\end{array}$ & 3.87 & $96.8 \%$ & Strongly Agree \\
\hline 2 & $\begin{array}{l}\text { Learning English via } \\
\text { Web-based } \\
\text { instructional model is } \\
\text { convenient to learn, } \\
\text { the lessons can be } \\
\text { reviewed anywhere } \\
\text { and anytime. }\end{array}$ & 3.94 & $98.6 \%$ & $\begin{array}{l}\text { Strongly } \\
\text { Agree }\end{array}$ \\
\hline 3 & $\begin{array}{l}\text { Learning English via } \\
\text { Web-based instruction } \\
\text { is the way to enhance } \\
\text { your self-directed } \\
\text { learning. }\end{array}$ & 3.80 & $94.9 \%$ & $\begin{array}{c}\text { Strongly } \\
\text { Agree }\end{array}$ \\
\hline 4 & $\begin{array}{l}\text { Learning English via } \\
\text { Web-based } \\
\text { instructional model is } \\
\text { enjoyable. }\end{array}$ & 3.93 & $98.1 \%$ & $\begin{array}{l}\text { Strongly } \\
\text { Agree }\end{array}$ \\
\hline 5 & $\begin{array}{l}\text { Learning English via } \\
\text { Web-based instruction } \\
\text { don't make you feel } \\
\text { isolated or alone. }\end{array}$ & 3.81 & $95.4 \%$ & $\begin{array}{l}\text { Strongly } \\
\text { Agree }\end{array}$ \\
\hline 6 & $\begin{array}{l}\text { Learning English via } \\
\text { Web-based } \\
\text { instructional model is } \\
\text { useful in learning } \\
\text { English }\end{array}$ & 3.89 & $97.2 \%$ & $\begin{array}{l}\text { Strongly } \\
\text { Agree }\end{array}$ \\
\hline 7 & $\begin{array}{l}\text { Learning English via } \\
\text { WBI helps you } \\
\text { remember more new } \\
\text { English words. }\end{array}$ & 2.83 & $70.8 \%$ & Agree \\
\hline 8 & $\begin{array}{l}\text { Learning English via } \\
\text { Web-based } \\
\text { instructional model has } \\
\text { clear explanation of } \\
\text { contents and exercises. }\end{array}$ & 2.98 & $74.5 \%$ & Agree \\
\hline 9 & $\begin{array}{l}\text { Learning English via } \\
\text { Web-based instruction } \\
\text { has the appropriate } \\
\text { contents with learning } \\
\text { objectives. }\end{array}$ & 3.80 & $94.9 \%$ & $\begin{array}{l}\text { Strongly } \\
\text { Agree }\end{array}$ \\
\hline 10 & $\begin{array}{l}\text { Learning English via } \\
\text { Web-based } \\
\text { instructional materials } \\
\text { is easy to understand } \\
\text { the lessons. }\end{array}$ & 3.33 & $83.3 \%$ & $\begin{array}{l}\text { Strongly } \\
\text { Agree }\end{array}$ \\
\hline 11 & $\begin{array}{l}\text { Overall, learning } \\
\text { English via Web-based } \\
\text { instructional materials } \\
\text { is satisfied. }\end{array}$ & 3.80 & $94.9 \%$ & $\begin{array}{c}\text { Strongly } \\
\text { Agree }\end{array}$ \\
\hline & Average Score & 3.63 & 90.9\% & $\begin{array}{c}\begin{array}{c}\text { Strongly } \\
\text { Agree }\end{array} \\
\end{array}$ \\
\hline
\end{tabular}

This value indicates that the students had very good opinions toward learning English via Web-based instruction. Considering each item, the students agree that learning English by using Web-based instruction is modern, with the highest percentage $96.8 \%$. They agree that learning via Web-based instruction is useful. They also agree that learning via Webbased instruction is convenient to learn since a person can review the lessons anywhere and anytime (98.6\%). Learning via Web-based instruction is a way to enhance their selfdirected learning $(94,9 \%)$ and this way of learning can help them remember more new vocabulary $(70.8 \%)$ which is classified as agree. The students agree that learning via Webbased instruction is enjoyable with the percentage score $98.1 \%$ and easy to understand the lessons with the percentage score 83.3\%. They agree that learning English via Web-based instructional materials has clear explanations of contents and exercises with the percentage score $74.5 \%$. The students express that learning English through Web-based instructional materials does not make them feel isolated or alone with the highest score $95.4 \%$.

In conclusion, according to the percentage score of the questionnaire $90.9 \%$ classified as strongly agree. It shows that the students had very good attitudes toward learning English via Web-based instructional materials. Having good attitudes and highly motivated are indicators of independent learning attitudes. While response given by the General English lecturers are shown below:
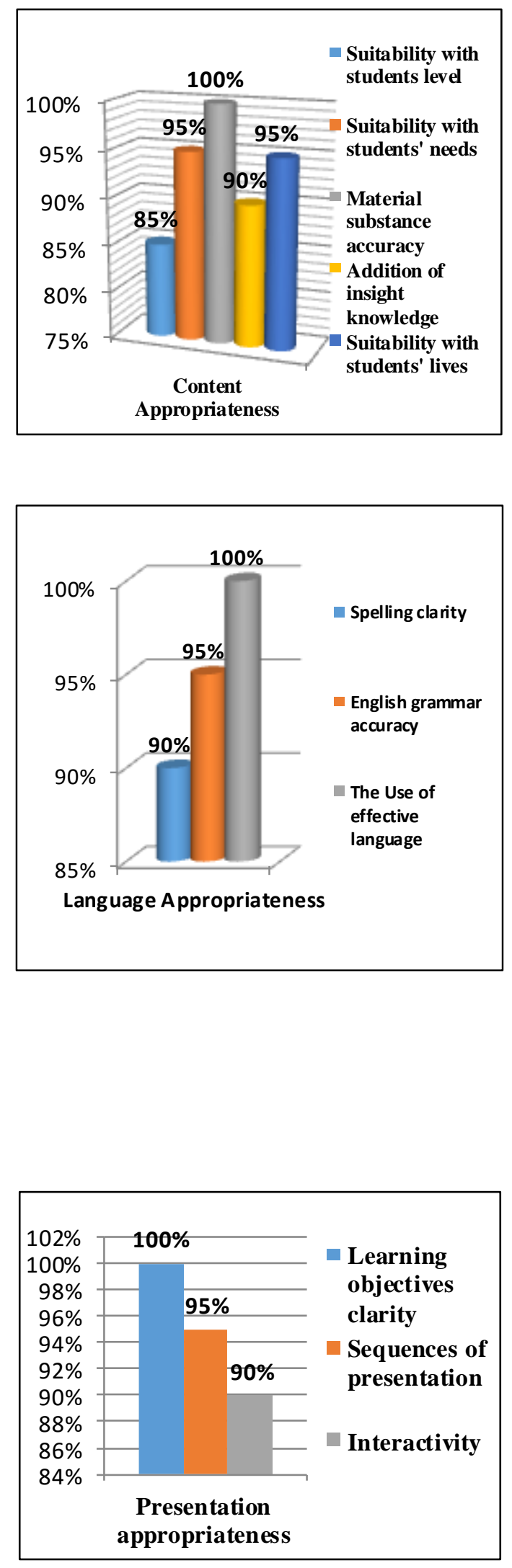


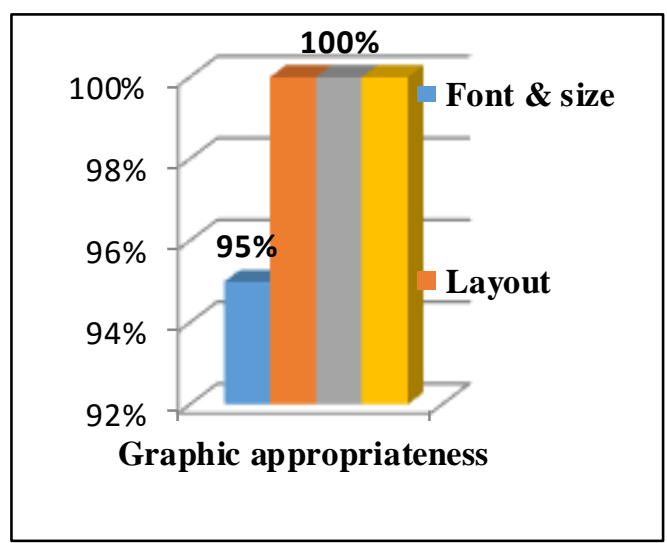

From the above data, we can comprehend that the contents within the Web-based instructional materials meet with the students' level of capabilities as well as meet their needs shown from the high percentages which are above $80 \%$. The materials substances are accurate and can improve students' insight of knowledge. Moreover, according to the lecturers asked, the Web-based materials are very contextual and in accordance to students' daily lives.

Finally, the average score of lecturers' responses is $95.3 \%$ which indicates that from the content, language, presentation and graphic overall shows suitability both by English materials standard and to students

The responses that the participants provided to the interview questions are analyzed by content analysis. The following response has been provided by a participant reflects the case clearly.

Question 1: Do you like learning general English Course by using Web-based instructional materials? Why or why not?

"Ten students said that they liked it because learning via Web-based instruction was convenient. They could study, review, and practice the lessons anywhere and anytime they wanted"

"Five students convey that learning via Web-based instructional materials promoted them to be independent learners. They can learn constantly on their own without the lecturer. It was fun learning through Web-based materials with various activities, they said"
Question 2: What do you like and dislike most when learning English through Web-based instructional materials?

There are three different opinions concerning this question:

Seven students said that the topic of the materials particularly the speaking practice encourage us to find partner or organize group to practice. This activity stimulates us to keep talking and communicate among us. The topic was clear enough to understand. The level of difficulty of the materials was suitable for our learning ability.

Four students assumed that the exercises and the assignments are challenging. They help us to understand more by doing the exercises. When we did the exercises or the assignment, we could check the answer from the answer key provided and recognize the level of our learning mastery or achievement. What is more, the exercises or the assignments were suitable for our learning ability.

Four students like the video animation. It is clear pronunciations and interesting conversation topics. They really encourage us to practice the conversation on the video animation.

Question 3: Are you convenient learning by equipped with Web-based English instructional materials? If not, what are problems? Would you give any suggestions or comments?

Most of the students are well-situated with the Web-based materials, nevertheless, they sometimes found the speed of the internet connection was slow. Therefore, they felt fed up while waiting for the network connection.

Another problem that encountered by students were when they used the materials out of campus and need helps or assistances from the lecturer but they can't do that immediately. Although the Web-board or chat forum is available, they have to wait for the lecturer's responses or comments on the chat forum.

Question 4: How should the Web-based English instructional materials be adjusted to meet your needs?

Four students said that Web-based instructional materials should be well- organize with learning menus and animated picture design.

Four students suggested that each exercise and test should provide the answers with explanations to facilitate more understanding.

Seven students recommended that this Web-based instruction should have a variety of topics or themes, not only used when we study English for general course but the learning materials are still available to be used for the next time for practicing.

Question 5: Would you like the next ESP course used Webbased English instructional materials?

For this question, all students reacted positively. We prefer to have Web-based instructional materials, present the materials by integrated skills. Further, the topic should much 
focus on our background study program, in other words more specific in terms of purposes.

There were three lecturers interviewed concerning the practicality or utility, the appropriateness, and the effectiveness of Web-based English instructional materials in promoting independent learning.

Question 1: How do you think the practicality of the teaching by using Web-based English instructional materials?(Practicality)

This Web-based instructional materials is really useful for me. Since the materials have been provided and suitable for my students' need and expectation. The various contents which equipped with authentic materials such as audio-visual, authentic conversation from native speakers are valuable (lecturer 1)

The Web-based instructional materials enable students to get real and authentic examples of the language expressions (lecturer 2)

The students become more enthusiastic, give more attention in learning by the means of Web-based instructional materials (lecturer 3)

Question 2: Are the contents of the Web-based instruction accurate for teaching English as general course?

The topics presented can engage the students to learn. The design of the presentation that displays integrated language skills relevant with the level of the students (lecturer 1)

The Web-based instructional materials make the classroom more enjoyable and potential to promote independent learning because of the various activity that can be accessed anytime and anywhere (lecturer 2)

The process of teaching and learning are more interesting and the students have more attention to the subject I teach (lecturer 3)

Question 3: How do you think the effectiveness of the Webbased instructional materials?

The whole packages are included; Speaking, Listening, Reading and Writing and language functions are presented so students are able to practice their language skills interchangeable (lecturer 1)

Because of the open resources software program so we are as authorized lecturers can edit the materials whenever needed. It is very effective (lecturer 1)

I can give feedback immediately to the students works or their assignment even response to their problem faced (lecturer 2)

With the various activities in Web-based materials, they enable to eliminate the boring situation, making the classroom alive. In short, the Web-based instructional materials can create language learning easier and more successfully managed (lecturer 3)

The exclusive feature of Web-based instructional materials is on how it offers learners to unparalleled access to instructional resources that surpasses the reach of the traditional classroom. The flexibility of the learning atmosphere allows students to access the materials anytime and anywhere. This lets them to not solely depend on the teachers and classroom to study. Its accessibility creates continuous practice of students accessing materials by their own and eventually promotes independent learning in the future if maintained in a sustainable routine.

\section{CONCLUSION}

The integration of web-based English instructional materials has brought changes and positive impact to the students. The standards and indicators of students' independent learning are achieved through web-based English instructional materials. This is indicated from the students' opinions toward the content, audio-visual materials that are proven to be very positive and appropriate to be used as instructional materials. The students agree that the flexile learning atmosphere along with the interactive and resourceful materials, allow them to be attracted and motivated in learning independently. The fun learning atmosphere and Learning: Management and Policy Considerations. CIEL the flexibility of lecturers' teaching method as the main feature of Web-based instructional materials are very appropriate for students particularly in helping them to be independent learners. The fact that users are able to access the materials with minimum training and do not depend on the presence of teachers prove to help students to be motivated in learning independently.

\section{REFERENCES}

[1] Suriaman, A. (2015). Strategies in promoting independent learning through self-access centre at Tadulako University. Asian EFL Journal - Professional Teaching Article (88).

[2] Sheerin, S. (1997). An Exploration of the Relationship Between Self-access and Independent Learning. . Oxford: Oxford University Press.

[3] CIEL Project. (2000). Integrating Independent Language. Management and Policy Considerations. CIEL.

[4] Liu, H. (2013). Constructing a Web-based autonomous learning model for teaching English. World Transactions on Engineering and Technology Education, 11 (4)

[5] Tabatabaei, M., Gui, Y. (2011). The Impact of Technology on Teaching and Languages. Education in a technological world: communicating current and emerging research and technological efforts. A. Méndez-Vilas (Ed.)

[6] Jaeglin. (1998). Learner's and Instructors' Attitudes Towards Computer-assisted Class Discussion. In S. J., R. S., M. P., \& A. K., Language Learning Online: Theory and Practice in the ESL and L2 Computer Classroom (pp. 121-138). Austin: Daedalus Group Inc.

[7] Mahmoudi, E., Samad, A., \& Razak, N. (2012). Attitude and Students' Performance in Computer Assisted English Learning (CAELL) for Learning Vocabulary. In 
Procedia-Social and Behavioural Sciences 66 (pp. 489498).

[8] Alexander, S. (1995). Teaching and Learning on the World Wide Web. Web 95: The First Australian World Wide Web Conference. New South Wales: Southern Cross University.

[9] Hadjerrouit, S. (2010). Developing Web-based learning Resources in School Education: A User-centered Approach. Interdisciplinary Journal of E-LEarning and LEarning Objects , 6.

[10] Aminah. (2016). Student and Teacher Perceptions on the Role of ICTS in Promoting Instruction for Quality Teaching and Learning in Central Sulawesi, Indonesia. Asian EFL Journal - Professional Teaching Article Indonesian. International Conference Edition December 2016, Volume 1. 